\title{
Membangun Etika Bisnis dalam Industri Pariwisata Melalui Program Pengabdian Masyarakat di Ketapanrame, Mojokerto, Jawa Timur
}

\author{
Veni Megawati ${ }^{1}$, Aluisius Hery Pratono ${ }^{2}$, Teguh Wijaya Mulya ${ }^{3}$, Delta A. Prima ${ }^{4}$ \\ ${ }^{1,2}$ Fakultas Bisnis dan Ekonomika, ${ }^{3}$ Fakultas Psikologi, , ${ }^{3}$ Fakultas Tehnik, Universitas Surabaya \\ E-mail: ${ }^{1}$ veni.megawati@ubaya.ac.id, ${ }^{2}$ hery_pra@staff.ubaya.ac.id, ${ }^{3}$ teguh@staff.ubaya.ac.id
}

\begin{abstract}
Abstrak
Artikel ini bertujuan untuk mengkaji upaya membangun etika bisnis dalam industri pariwisaya melalui program pengabdian masyarakat yang dilaksanakan di Desa Ketapanrame, Mojokerto Jawa Timur. Pelaksanaan program ini menggunakan beberapa pendekatan mulai dari workshop, studi banding, serta self-assessment yang melibatkan partisipasi warga masyarakat. Hasil kajian menunjukan keberhasilan upaya membangun etika bisnis dalam industri pariwisata ditentukan oleh dinamika organisasi pengelola unit usaha termasuk hubungannya dengan para pemangku kepentingan. Selain itu, munculnya wabah Covid-19 menunjukan bahwa lingkungan bisnis yang sangat dinamis sangat menentukan upaya membangun etika bisnis dalam industri pariwisata.
\end{abstract}

Kata kunci: tourism ethics, cultural, diversity, empowerment, and engagement

\begin{abstract}
This article seeks to understand how a tourism industry promotes the business ethics through community development program in Ketapanrame Village, Mojokerto East Java. The program adopts various approaches from workshop, comparison studies, and self-assessment, which involve community participation. The results indicate that the capacity of the local leaders and their relationship with the community organizers. In additional, the phenomena of Covid19 also provides dynamic business environment, which encourage new ethics behaviour in tourism industry.
\end{abstract}

Keywords: etika wisata, keberagaman budaya, pemberdayaan, dan keterlibatan

\section{PENDAHULUAN}

Dalam dasa warsa terakhir, diskusi mengenai etika dalam industri pariwisata mendapatkan perhatian yang cukup serius [1]. Etika dianggap sebagai kajian akademis yang dibutuhkan untuk keberhasilan industri pariwisata [2]. Alasannya adalah bahwa para profesional dan bisnis perhotelan dihadapkan pada sejumlah isu yang cukup sensitif, seperti tingginya gratifikasi pada layanan, penyalahgunaan konsumsi alkohol dan zat lain [3], adanya aktivitas kriminal yang dalam industri pariwisata, [4] serta eksploitasi sumber daya alam yang berlebihan. Sementara itu, etika dalam perhotelan dan pariwisata cenderung didominasi oleh isu sumber daya manusia, keberlanjutan, dan tanggungjawab sosial [1].

Inovasi dalam industri pariwisata memunculkan tantangan mengenai etika. Beberapa pertanyaan antara lain: bagaimana standar kesehatan untuk produksi makanan dan minuman [4], bagaimana perkembangan model bisnis lokal dalam lingkungan industri pariwisata yang dinamis [5], bagaimana pola konsumsi masyarakat lokal berubah dengan penyesuaian dengan gaya hidup wisatawan asing [6]. Pada saat yang sama, dapat dikatakan bahwa kerangka kerja etika yang berkembang bertindak sebagai sumber inovasi. Jika sebelumnya menawarkan makanan yang tidak sehat atau berlebihan dianggap sebagai praktik bisnis yang etis, saat ini bahkan rantai makanan cepat saji mengiklankan pilihan yang bertanggung jawab, dan semakin 
banyak restoran yang merangkul inisiatif pengurangan limbah makanan. Praktik HRM yang berkelanjutan telah diidentifikasi sebagai solusi terhadap pergantian dan kekurangan staf. Masalah lingkungan telah menginspirasi inovasi dalam arsitektur hotel dan desain operasi.

Kode etik global UNWTO (2001) memberikan kerangka kerja sukarela dasar bagi operator pariwisata, pembuat kebijakan dan pemangku kepentingan lainnya tentang etika, dengan kewajiban seperti mengobarkan pemahaman dan rasa hormat antara masyarakat dan masyarakat [7]. Tujuannya adalah untuk berkontribusi pada pemenuhan individu dan kolektif sebagai faktor kunci dalam pembangunan berkelanjutan dan dalam merangkul warisan budaya. Tujuan Pembangunan Berkelanjutan PBB (2015) memberikan agenda yang ambisius untuk industri global karena semakin banyak organisasi memasukkan tujuan ini dalam pernyataan misi mereka. Mereka diharapkan, misalnya, berkontribusi untuk memberantas kemiskinan (Tujuan 1), memastikan hidup sehat dan meningkatkan kesejahteraan (Tujuan 3), mencapai kesetaraan gender (Tujuan 5), mengurangi ketidaksetaraan di dalam dan di antara negara-negara (Tujuan 10 ) dan untuk memastikan pola konsumsi dan produksi yang berkelanjutan (Tujuan 12).

Desa Ketanrame terletak di Kecamatan Trawas, yang merupakan kawasan wisata di bagian selatan Kabupaten Mojokerto, Jawa Timur. Dengan ketinggian rata-rata $600 \mathrm{~m}$ di atas permukaan laut, kawasan ini merupakan wilayah pegunungan yang subur dengan suhu udara yang cukup sejuk, sehingga menjadi kawasan wisata dengan populasi vila dan hotel cukup tinggi. [1] Hingga tahun 2018, warga Desa Ketapanrame merasa kurang mendapatkan manfaat dari keberadaan industri pariwisata di kawasan tersebut. BUMDes sebagai badan usaha milik desa masih mengandalkan pendapatan dari penjualan air minum. Melalui Unit Usaha "Tirto Tentrem" yang dibentuk tahun 1988, BUMDes Ketapanrame memasok kebutuhan air bersih masyarakat dengan menyediakan pipa dan bak penampungan air. Dalam perkembangannya, unit usaha ini juga melayani kebutuhan air bersih untuk termasuk vila dan hotel, serta memasok air isi ulang. Namun demikian, keterbatasan sumber air dan semakin meningkatnya populasi vila dan hotel menyebabkan potensi konflik sumber daya air.

Tujuan Program Pengabdian Masyarakat Unggulan Perguruan Tinggi ini adalah membantu masyarkat Desa Ketapanrame memecahkan masalah ketergantungan pada sumber daya air yang dikelola oleh BUMDES. Lembaga ini berusaha mendapatkan alternatif penghasilaan dengan mempromosikan pariwisata sebagai sumber pendapatan alternatif serta melibatkan generasi muda untuk melestarikan budaya lokal yang dapat mengurangi jumlah pengangguran maupun arus urbanisasi ke kota. Secara khusus, artikel ini akan membahas pelaksanaan penerapan etika wisata di Kawasan Taman Ghanjaran dengan mengadopsi kode etik UNWTO.

\section{METODE}

Metode yang digunakan dalam Pengembangan Wisata Desa Ketapanrame ini dilaksanakan melalui tiga metode yaitu,

\subsection{Sosialisasi}

Sosialisasi merupakan langkah awal dalam pelaksanaan program, yang menentukan keberlanjutan keberlanjutan program. Kegiatan ini mengadopsi beberapa metode sosialisasi, seperti 1) sosialisasi langsung, yaitu interaksi langsung oleh para dosen pendamping kepada masyarakat. Metode ini paling efektif karena fasilitator berhadapan langsung dan memberikan penjelasan terkait program sehingga mampu mengurangi kesalahfahaman karena masyarakat mendapatkan informasi langsung dari sumbernya. Metode ini dilakukan dengan menghadiri pertemuan RT, arisan, pertemuan tingkat desa, tahlilan atau saat cangkrukan di balai desa. Namun demikian, munculnya wabah Covid19 menyebabkan sosialisasi ini hanya bisa dilakukan pada tahun pertama saja.

Setelah merebaknya wabah Covid 19, sosialisasi pada pendampingan tahun kedua 
dilakukan dengan pendekatan tidak langsung, yaitu melalui perantara aparat desa baik Kepala Desa, Ketua BUMDes maupun Sekretaris Desa. Metode ini efisien dari segi waktu, namun kurang menjamin dari segi hasil karena masyarakat tidak mendapatkan informasi langsung dari sumbernya. Ada risiko kegagalan yang muncul karena kesalahpahaman ketika tim pendamping meminta bantuan aparat desa, tokoh masyarakat, atau salah satu warga untuk mensosialisasikan program kepada masyarakat, tanpa didampingi oleh fasilitator. Para dosen pendamping tidak dapat mendengar langsung pendapat masyarakat mengenai harapan dan kekawatiran mereka terhadap pelaksanaan program ini.

\subsection{Pendampingan}

Pendampingan yang dilakukan dalam program ini mengadopsi pendekatan partisipatif, konsultatif, dan delegative. Pendekatan ini dipilih setelah tahun pertama kegiatan ini berhasil dilakukan dengan dukungan penuh dari kepala desa, jajaran pemerintah, serta tokoh masyarakat setempat. Pendekatan partisipatif yang dilakukan mulai dari identifikasi harapan masyarakat dan stakeholder dalam pengembangan kawasan Taman Ghanjaran, selanjutnya identifikasi kebutuhan program yang selaras dengan tujuan PPMUPT.

Tahap pelaksanaan sepenuhnya diserahkan ke masyarakat karena masyarakat mempunyai minat yang cukup tinggi untuk pengembangan kawasan wisata ini. Hal ini terbukti bahwa penggalangan dana masyarakat untuk pembangunan wahana wisata di kawasan ini pada 2020 bisa mencapai Rp 3 milyar. Dengan kata lain, PPMUPT merupakan program pendukung dalam mengembangkan pariwisata di Desa Ketapanrame.

Pemerintah Desa Ketapanrame cukup terbuka untuk mewujudkan tatalaksana pemerintahan yang baik (good governance). Pendampingan kegiatan ini termasuk proses pemilihan kepala desa pada 2019 di mana masing-masing calon memaparkan pengembangan kawasan ini. Tim Pendamping dari UBAYA diminta untuk terlibat dalam memfasilitasi ruang dialog antara para calon kepala desa dan warga. Keputusan tentunya sepenuhnya di tangan warga, namun tim pendamping mengarahkan pada norma dan etika.

Tentu saja tidak ada satu metode pendampingan yang paling efektif, karena kondisi masyarakat cukup bervariatif. Berdasarkan pengamatan, beberapa sikap masyarakat bisa dikelompokan ke dalam 4 tahapan, yaitu: (1) tahap belum ada kesadaran sehingga tidak mau melakukan dan tidak mampu melakukan, (2) tahap sadar meskipun mampu melakukan, (3) tahap adanya kesadaran untuk mau melakukan tetapi belum mampu melakukan, dan (4) tahap keterlibatan penuh karena mau dan mampu melakukan. Pendekatan ini dipilih menyesesuaikan tingkat perkembangan masyarakat yang didampingi.

\subsection{Monitoring}

Keberhasilan suatu program dapat dilihat dari kesesuaian antara perencanaan dan pelaksanaannya, terukur atau akuntabel hasilnya, serta ada keberlanjutan aktivitas yang merupakan dampak dari program itu sendiri. Untuk memastikan hal tersebut, monitoring kegiatan program ini menggunakan dua macam pendekatan dalam melakukan monitoring, yaitu: survey awal, dan exspost facto atau pengamatan setelah pelaksanaan kegiatan. Paling tidak ada empat tujuan yang dapat dicapai melalui survei, yaitu: deskriptif, eksplanatif, eksploratif, dan prediktif. Pendekatan survei deskriptif digunakan untuk mendeskripsikan keadaan dan kondisi subyek dan atau obyek yang dimonitoring dan evaluasi (monev). Pendekatan exspost facto digunakan bila monev dilakukan untuk mencari dampak program yang telah dilakukan. Dengan demikian, bila monev itu tidak dimaksudkan untuk mencari dampak akibat perlakuan di masa lampau maka pendekatan ini tidak disebut dengan exspost facto.

Monitoring dilakukan dengan pendekatan diskusi, bertukar pikiran, mengevaluasi alternatif, maupun mengidentifikasi risiko yang muncul dalam mengambil kebijakan. Persiapan sebelum rapat evaluasi, khususnya dengan reviewer mendapatkan hasil yang lebih baik, karena 
kontribusi setiap peserta dalam mengerjakan tugas-tugas sangat dihargai. Simulasi evaluasi dengan reviewer memberikan kesempatan untuk mengantisipasi berbagai pertanyaan dari reviewer.

Diskusi dengan para pemuka masyarakat setempat dengan menggunakan pendekatan "pertanyaan berjenjang", yaitu proses diskusi dengan mengajukan pertanyaan, kemudian melanjutkan baris pertanyaan mereka berdasarkan tanggapan peserta. Diskusi dimulai dengan menggali cerita tentang perkembangan Taman Ghanjaran. Mengapa mereka memilih membangun Taman Hiburan. Pertanyaan berikutnya adalah "bagaimana mereka akan beradaptasi dengan kondisi Covid saat ini. Dialog ini merupakan diskusi yang terstruktur sangat longgar - karena pewawancara tidak mengetahui bagaimana partner akan menanggapi pertanyaan awal mereka sebelumnya. Diskusi diharapkan dapat membentuk nilai-nilai inti para peserta. Misalnya, mengetahui bagaimana partisipasi masyarakat akan mendorong kualitas layanan pariwisata di Desa Ketapanrame.

Pendekatan kedua adalah menggali permasalahan yang tersembunyi. Pelaksana program mencoba untuk mencari tahu bagaimana etika dalam mempromosikan pariwisata lokal. Diskusi ini bukan hanya membahas nilai-nilai yang dibagikan secara sosial seperti hak asasi manusia atau melanggar hukum, tetapi fokusnya lebih pada masalah pribadi yang dihadapi secara mendalam. Masalah ini tidak mudah diungkapkan melalui pertanyaan langsung, jadi pewawancara harus berhati-hati dalam mengeluarkan informasi semacam ini dari peserta. Diskusi dimulai tentang harapan mereka terhadap kehidupan ideal, atau visi dunia yang sempurna. Berdasarkan jawaban mereka, pewawancara dapat melanjutkan pertanyaan mereka untuk menentukan ciri-ciri apa yang akan dikecualikan dari kehidupan sempurna mereka. Misalnya, menentukan bahwa mereka tidak ingin merasa canggung dalam lingkungan sosial atau menekankan daya tarik produk kepada lawan jenis, dan kemungkinan akan menarik perhatian peserta lebih dari sekadar menekankan masalah ekonomi.

Pendekatan ketiga adalah analisis simbolik. Pendekatan ini untuk mengetahui apa yang dipikirkan masyarakat berdasarkan simbul-simbul yang diamati dengan menanyakan tentang peran Taman Ghanjaran. Ini adalah teknik untuk mencari tahu apa arti Taman Ghanjaran bagi peserta. Diskusi dimulai dengan pertanyaan kepada peserta apakah mereka secara teratur menggunakan sosial media. Jika demikian, apa yang akan dilakukan peserta jika sosial media tidak tersedia? Peserta mungkin menjawab bahwa mereka hanya mengambil foto untuk kenangkenangan saja dan tidak membagikan ke orang lain. Dari sini, pewawancara dapat menyimpulkan bahwa, bagi partisipan, sosial media merupakan cara untuk tetap berhubungan dengan Taman Ghanjaran. Informasi semacam ini dapat membantu BUMDEs menentukan cara beriklan.

\section{HASIL DAN PEMBAHASAN}

\subsection{Profil Partisipan}

Artikel ini secara khusus membahas unit pengelolaan wisata desa yang mengandalkan kawasan wisata Taman Ghanjaran. Kawasan ini diresmikan oleh Bupati Mojokerto pada tanggal 8 Desember 2018. Wisata Taman Ghanjaran terletak di jalur utama Mojokerto-Tretes (Pasuruan). Nama ini dipilih karena kawasan ini berdiri di atas tanah kas desa yang digunakan oleh perangkat untuk tambahan gaji. Lokasi yang strategis memunculkan ide untuk menjadikan tanah tersebut sebagai kawasan wisata yang diharapkan mampu menambah pendapatan perangkat desa dan ekonomi masyarakat.

Konsep awal pembangunan kawasan wisata berupa taman terbuka, tempat istirahat, dan belanja mendapatkan dana bantuan dari Pemerintah Kabupaten Mojokerto. Sempat ada wacana untuk mengundang investor dengan risiko pengelolaan sepenuhnya di bawah kendali mereka. Namun dengan adanya dukungan Pemerintah Kabupaten berupa bantuan dana sebesar 4 milyar, 
maka gagasan kawasan wisata bisa terwujud yang sepenuhnya bisa dikelola oleh warga. Kemudian dibentuklah TPK (Tim Pengelola Kegiatan) yang bertanggungjawab untuk melaksanakan kegiatan pembangunan kawasan wisata tersebut. Selanjutnya, BUMDes mendapatkan kewenangan untuk mengelola.

Badan Usaha Milik Desa (BUMDes) Ketapanrame, Kecamatan Trawas, Kabupaten Mojokerto, masuk enam besar dalam perlombaan BUMDes Se- Jawa Timur pada 2020 berdasarkan surat Dinas Pemberdayaan Masyarakat dan Desa (DPMD) Provinsi Jawa Timur Nomor 412.2/5885/112.3/2020. Lembaga ini memiliki lima unit usaha, yaitu jasa pengelolaan air minum, jasa pengelolaan kebersihan lingkungan, jasa pengelolaan kios, pengelolaan wisata desa, serta simpan pinjam dan kemitraan.

\subsection{Temuan}

\section{(1) Pariwisata memberikan ruang untuk setiap orang untuk saling memahami dan menghormati}

Nilai-nilai etika pariwisata global menjunjung tinggi sikap toleransi dan penghormatan terhadap keragaman agama, filosofi dan keyakinan moral. Pengembangan pariwisata dan wisatawan menghargai tradisi dan praktik sosial dan budaya semua masyarakat, termasuk minoritas dan masyarakat adat dan untuk mengakui nilai mereka. Kegiatan pariwisata di Ketapanrame selaras dengan atribut dan tradisi lokal dan dengan menghormati hukum, praktik dan adat istiadat setempat. Hal ini ditunjukan dengan kegiatan seni pertunjukan lokal seperti bantengan, keroncong, maupun perayaan hari keagamaan.

BUMDes Ketapanrame sebagai pengelola berusaha mengenal dan menghormati para wisatawan yang mengunjungi kawasanb ini dengan mencari tahu tentang gaya hidup, selera dan harapan mereka. Program-program pendidikan dan pelatihan yang diberikan kepada para profesional berkontribusi pada sambutan yang ramah.

Tim pengelola berusaha memberikan perlindungan bagi wisatawan dan pengunjung terutama kesehatan mereka dengan menerapkan prosedur keamanan dan kesehatan di kawasan wisata. Mereka memberi perhatian khusus pada keselamatan turis dari luar kota karena kerentanan khusus yang mungkin mereka miliki dengan pengenalan cara-cara khusus untuk informasi, pencegahan, keamanan, dan bantuan yang sesuai dengan kebutuhan mereka. Demikian juga dengan risiko terjadinya kejahatan seperti penyerangan, penculikan atau ancaman terhadap wisatawan atau pekerja di industri pariwisata dengan bekerjasama dengan apparat kepolisian setempat. Tentunya para pengunjung didorong untuk menyadari adanya risiko kesehatan dan keamanan dalam kondisi pandemik Covid-19 dengan berperilaku sedemikian rupa untuk meminimalkan risiko tersebut.

\section{(2) Kawasan pariwisata menjadi sarana bagi setiap individu maupun masyarakat umum untuk memenuhi kebutuhannya}

Pariwisata sering kali dikaitkan dengan suasana istirahat dan relaksasi, serta akses ke budaya dan alam. Oleh karena itu, Taman Ghanjaran dikelola dengan mengadopsi konsep keberagaman dengan memfasilitasi berbagai macam seni pertunjukan mulai dari wayang orang. Penyediaan sarana bagi pemenuhan individu dan kolektif yang dipraktekkan dengan pikiran yang cukup terbuka memberikan ruang bagi pendidikan diri yang tak tergantikan, saling toleransi dan untuk belajar tentang perbedaan antara masyarakat dan budaya serta keragaman mereka. Taman Ghanjaran mencoba menghilangkan kesan negative yang pernah muncul akibat merebaknya bangunan vila dan hotel di kawasan ini. Eksploitasi manusia dalam bentuk apapun, terutama seksual, terutama bila diterapkan pada anak-anak, bertentangan dengan tujuan fundamental pariwisata dan merupakan negasi dari pariwisata, khususnya Taman Ghanjaran. 


\section{(3) Pariwisata merupakan pendukung pembangunan berkelanjutan}

Pembangunan kepariwisataan dituntut untuk menampilkan kondisi lingkungan alam yang mampu mendorong pertumbuhan ekonomi yang sehat dan berkelanjutan yang diarahkan untuk memenuhi secara adil kebutuhan dan aspirasi generasi sekarang dan yang akan datang. Oleh karena itu, berbagai bentuk pembangunan pariwisata dituntut untuk menyelamatkan sumber daya langka dan berharga, khususnya air dan energi. Taman Ghanjaran menjadi alternatif pendapatan desa, yang diharapkan dapat menggantikan ketergantungan dari penyediaan air minum.

Lonjakan kunjungan wisatawan akibat liburan sekolah maupun cuti bersama menimbulkan risiko tekanan terhadap kualitas lingkungan. Keberadaan Taman Ghanjaran menjadi alternatif untuk mengurangi beban arus wisatawan yang berkunjung ke Air Terjun Dlundung. Air Terjun Dlundung merupakan kawasan wisata alam yang menawarkan ekosistem dan keanekaragaman hayati dan untuk melestarikan spesies satwa liar. Wisata alam dan ekowisata diakui sangat kondusif untuk memperkaya dan meningkatkan kedudukan pariwisata, asalkan menghormati warisan alam dan penduduk lokal dan sesuai dengan daya dukung situs. Tantanganya adalah menyetujui penerapan batasan atau batasan pada kegiatan mereka ketika ini dilakukan di daerah yang sangat sensitive, khususnya di kawasan pegunungan tinggi.

\section{(4) Pariwisata Mendorong Pengembangan Warisan Budaya}

Sumber daya pariwisata adalah milik desa, sehingga masyarakat di wilayah mana mereka berada memiliki hak dan kewajiban tertentu kepada mereka. Kebijakan dan kegiatan pariwisata dilaksanakan dengan menghormati warisan seni, arkeologi dan budaya, yang harus dilindungi dan diwariskan kepada generasi mendatang. Meskipun dekat dengan peninggalan di Gunung Penanggungan, belum ada koordinasi khusus yang diberikan untuk melestarikan monumen, kuil dan museum serta situs arkeologi dan bersejarah. Belum ada dorongan yang diberikan kepada akses publik ke properti budaya dan monumen milik pribadi, dengan menghormati hak-hak pemiliknya, serta bangunan keagamaan, tanpa mengurangi kebutuhan ibadat normal. Sumber daya keuangan yang diperoleh dari kunjungan ke situs budaya dan monumen, setidaknya sebagian, harus digunakan untuk pemeliharaan, pengamanan, pengembangan dan penghias warisan ini.

\section{(5) Penduduk lokal sangat mengharapkan manfaat pariwisata}

Pengelola BUMDes Ketapanrame berusaha melibatkan penduduk lokal untuk mewujudkan pariwisata yang bermanfaat secara ekonomi, sosial dan budaya, dan khususnya dalam penciptaan lapangan kerja langsung dan tidak langsung yang dihasilkan dari mereka. Kebijakan pariwisata diterapkan sedemikian rupa untuk membantu meningkatkan taraf hidup penduduk lokal dan memenuhi kebutuhan mereka. Design pengembangan pariwisata berupaya berintegrasi dalam tatanan ekonomi dan sosial lokal dengan meningkatkan keterampilan tenaga kerja lokal setara dengan tenaga kerja pendatang. Dengan adanya BUMDes sebagai pengelola kawasan wisata, program-program yang dikembangkan membuka peluang adanya dialog dengan penduduk yang lebih besar dibandingkan dengan adanya investor swasta, khususnya mengenai program-program masa depan mereka.

\section{(6) Tanggungjawab pemangku kepentingan dalam pengembangan pariwisata}

Pengelola pariwisata di Ketapanrame berkewajiban untuk memberikan informasi yang obyektif dan jujur kepada wisatawan tentang tempat tujuan mereka dan tentang kondisi perjalanan, keramahtamahan, dan masa inap; mereka harus memastikan bahwa klausul kontrak 
yang diusulkan kepada pelanggan mereka mudah dimengerti mengenai sifat, harga, dan kualitas layanan yang mereka janjikan sendiri untuk diberikan dan kompensasi finansial yang harus dibayarkan oleh mereka jika terjadi pelanggaran kontrak sepihak di pihak mereka;

Sebagai pengelola kawasan, BUMDes menunjukkan kepedulian, dalam kerjasama dengan otoritas publik, untuk keamanan dan keselamatan, pencegahan kecelakaan, perlindungan kesehatan dan keamanan makanan dari mereka yang mencari layanan mereka; demikian pula, mereka harus memastikan adanya sistem asuransi dan bantuan yang sesuai; mereka harus menerima kewajiban pelaporan yang ditentukan oleh peraturan nasional dan membayar kompensasi yang adil jika terjadi kegagalan untuk mematuhi kewajiban kontrak mereka;

Dalam kondisi krisis akibat Covid 19, Pemerintah menginformasikan warganya tentang keadaan sulit dan bahaya yang mungkin mereka hadapi selama kunjungan ke kawasan wisata. Tentunya Pemberintah mengeluarkan informasi tersebut tanpa mengurangi dengan cara yang tidak dibenarkan atau dibesar-besarkan industri pariwisata negara tuan rumah dan kepentingan operator mereka sendiri. Oleh karena itu, isi dari travel advisories telah didiskusikan terlebih dahulu dengan otoritas negara tuan rumah dan profesional terkait; rekomendasi yang dirumuskan harus benar-benar proporsional dengan beratnya situasi yang dihadapi dan terbatas pada wilayah geografis tempat timbulnya ketidakamanan; nasihat tersebut harus memenuhi syarat atau dibatalkan segera setelah kembali ke izin normalitas;

Media masa maupun media sosial merupakan sarana promosi yang efektif. Mereka diharapkan mengeluarkan informasi yang jujur dan seimbang tentang peristiwa dan situasi yang dapat mempengaruhi arus wisatawan; mereka juga harus memberikan informasi yang akurat dan dapat diandalkan kepada konsumen jasa pariwisata. Keberadaan teknologi komunikasi memungkinkan pengunjung memberikan opini secara obyektif sehingga mendorong perkembangan dinamika sosial dan ekonomi.
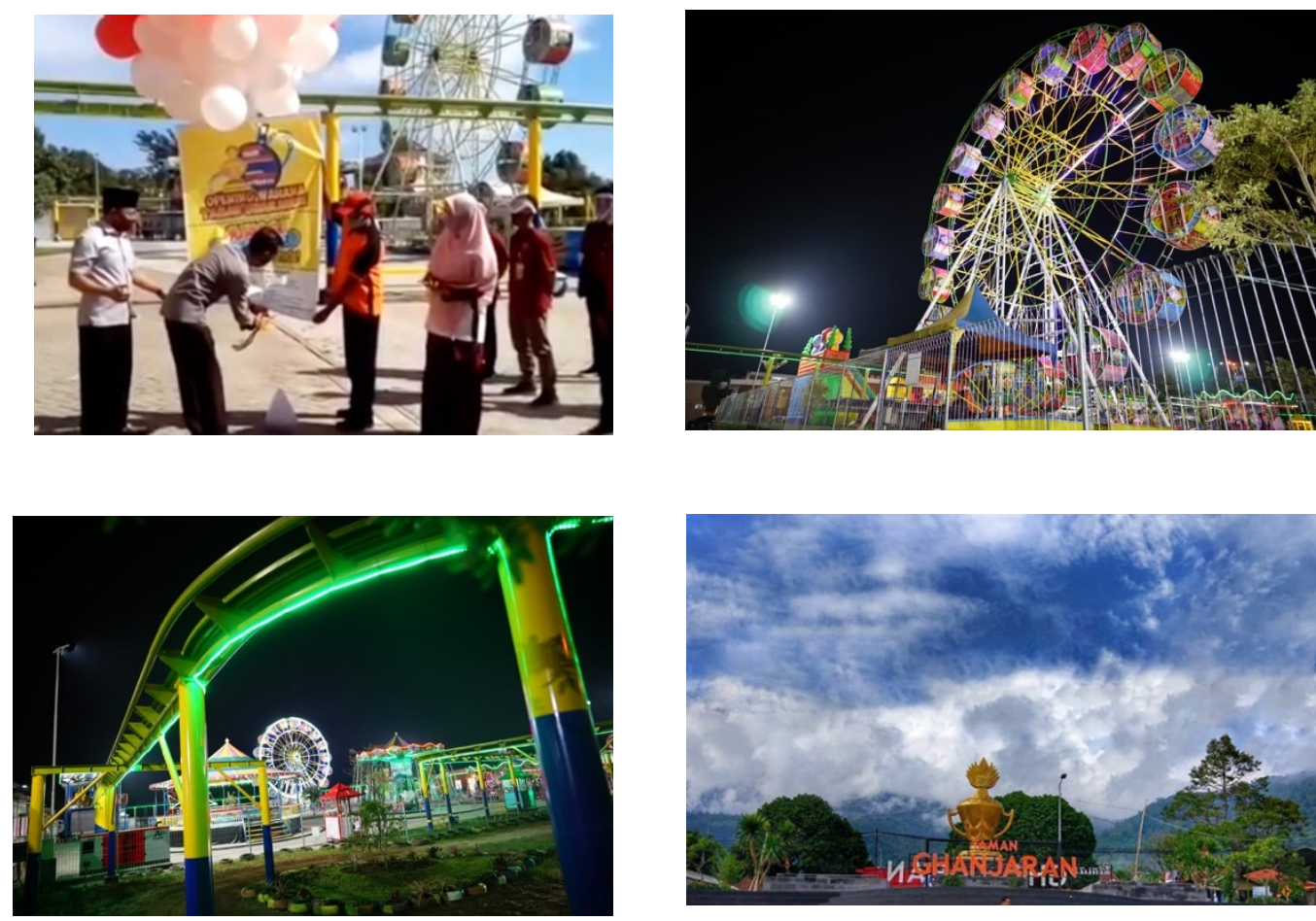

Gambar 1. Pembukaan Taman Ghanjaran selama masa pandemik 


\section{(1) Hak-hak para pekerja dan pengusaha di dunia pariwisata}

Dalam kondisi pandemik, situasi yang sulit terjadi dengan pekerja di kawasan ini. Sebagian besar merupakan pengusaha mandiri. Hak-hak dasar pekerja yang digaji dan wiraswasta dalam industri pariwisata dan kegiatan ini di bawah pengawasan pemerintah desa, mengingat kendala khusus terkait secara khusus dengan kegiatan musiman mereka, dimensi global industri mereka dan fleksibilitas yang sering mereka tuntut dari sifat pekerjaan mereka.

Pengelola BUMDES berusaha memberikan hak dan kewajiban bagi pekerja untuk memperoleh pelatihan yang berkelanjutan. Pandemik COVID-19 menuntut BUMDES berusaha menyediakan perlindungan sosial yang memadai. Ketidakamanan pekerjaan dibatasi sejauh mungkin dengan membatasi jumlah pengunjung, meskipun beberapa pekerja musiman mengeluhkan pembatasan tersebut. Setiap orang perorangan atau badan hukum diizinkan untuk mengembangkan kegiatan profesional di bidang pariwisata tersebut berdasarkan kesepakatan dengan pengurus BUMDES. Pengusaha usaha kecil dan menengah mendapatkan akses gratis ke sektor pariwisata dengan batasan hukum atau administratif minimum.

\section{KESIMPULAN DAN SARAN}

Pertukaran pengalaman yang ditawarkan kepada para penggiat pariwisata dan pekerja, baik yang digaji maupun tidak, memberikan kontribusi untuk mendorong perkembangan industri pariwisata dunia. Gerakan ini harus difasilitasi sejauh mungkin sesuai dengan hukum nasional yang berlaku dan konvensi internasional. Sebagai faktor solidaritas yang tak tergantikan dalam perkembangan dan dinamika pertumbuhan pertukaran internasional, BUMDes yang bergerak dalam industri pariwisata menghadapi tantangan antara mengeksploitasi sumber daya untuk kesejahteraan atau menahan diri untuk mendapatkan penghasilan besar dengan menjaga kualitas lingkungan. Mereka juga berusaha menghidari model bisnis yang mengeksploitasi budaya lokal secara artifisial untuk sekedar mendapatkan keuntungan finansial dalam jangka pendek. Sebagai imbalan atas kebebasan mereka untuk berinvestasi dan berdagang yang harus sepenuhnya diakui, mereka harus melibatkan diri dalam pembangunan lokal, menghindari, dengan repatriasi berlebihan dari keuntungan mereka atau impor yang dibujuk, pengurangan kontribusi mereka terhadap ekonomi di mana mereka didirikan.

\section{UCAPAN TERIMA KASIH}

Terimakasih kepada Kemenristek BRIN yang telah mendanai kegiatan ini melalui Program Pengabdian Masyarakat Unggulan Perguruan Tinggi. Artikel ini telah dipresentasikan dalam Seminar Nasional Hasil Pengabdian kepada Masyarakat (SEMAdiF 2020).

\section{DAFTAR PUSTAKA}

[1] Myung, E. (2018). "Progress in Hospitality Ethics Research: A Review and Implications for Future Research," International Journal of Hospitality \& Tourism Administration, Vol 19 No 1, pp. 26-51. 2018

[2] Buhalis, D., Harwood, T., Bogicevic, V., Viglia, G., Beldona, S., \& Hofacker, C. "Technological disruptions in services: lessons from tourism and hospitality," Journal of Service Management, Vol. 30 No 4, pp. 484-506. 2019

[3] Swanger, N., \& Gursoy, D. "An industry-driven model of hospitality curriculum for programs housed in accredited colleges of business: E-assessment tool (e-AT)-Part IV," Journal of Hospitality \& Tourism Education, Volume 22 No 2, pp 5-19. 2010 
[4] Reynolds, D. "An exploratory investigation into behaviourally based success characteristics of foodservice managers". Journal of Hospitality \& Tourism Research, Vol 24 No 1, pp. 92103. 2000

[5] Walsh, P. R., \& Dodds, R. (2017). "Measuring the choice of environmental sustainability strategies in creating a competitive advantage". Business Strategy and the Environment, Vol. 26 No. 5, pp. 672-687.

[6] Pratono, A.H. \& Radjamin, I.M. (2012) "Kopy Luwak: a conservation strategy for global market". Emerald Emerging Markets Case Studies, Vol. 2 No. 8, pp. 1-12.

[7] Pratono, A.H. \& Arli, D. (2020). "Linking global consumer culture and ethnocentric consumerism to global citizenship: exploring the mediating effect of cultural intelligence", International Journal of Sociology and Policy, Vol. 40 No. 7/8, pp. 659-675.

[8] UNWTO, Global Code of Ethics for Tourism. Madrid: 2001Walsh, http://www.unwto.org/global-code-of-ethics-for-tourism. Diakses pada 21 April 2021. 